\title{
Human Capital Investment and Its Role in Encouraging Inclusivity in East Java
}

\author{
Visi Saujaningati Kristyanto $^{\# 1}$, Setyo Tri Wahyudi ${ }^{\# 2}$ \\ ${ }^{\#}$ Faculty Economics and Business, Brawijaya University, Indonesia \\ ${ }^{1}$ setyo81@gmail.com
}

\begin{abstract}
Currently, inclusive growth is a key issue in economic development. Inclusive growth encourages individuals to access education, health and other components that promote better living standards. In East Java, despite high economic growth, the income inequality level is also relatively high. Therefore, government intervention is needed to encourage the growth of higher quality, one of them through human capital investment. The objectives of this research are (i) to identify the relationship between human capital investment and economic growth and (ii) to analyze the impact of human capital investment on community welfare. The method of analysis used is simultaneous regression method. The findings show that human capital investment significantly affects economic growth. This means, human capital investment can be used as policy alternatives to encourage growth inclusivity in East Java. Simultaneously, the impact of social capital investment encourages the welfare of society through increased labor in the tertiary sector. The government needs to allocate human capital investment that encourages higher education and skills to compete in the labor market.
\end{abstract}

Keywords — Regional Planning, Inclusive Growth, Human Capital Investment

\section{BACKGROUND}

There is a debate among development planners that the government's success in promoting economic growth is often not accompanied by an increase in the welfare of the people which characterized by declining unemployment, inequality of income and poverty. Empirical studies have shown that high economic growth is followed by rising unemployment, inequality and poverty. For example, the result of the 2014 Botswana study explains that public investment allocations for education fail to reduce unemployment. The implication is that many productive aged people do not receive decent work with an inadequate standard of living. In India, the economic growth rate of $9 \%$ is not proportional to the $28 \%$ poverty reduction [14]. Other studies in the Philippines show that most people do not benefit from the rapid growth of the economy, moreover the data show that poverty and unemployment rates have not decreased significantly [9].
Regarding of how to measure the welfare? Since 2007, there has introduced a concept to measure the welfare which more comprehensive. This concept is known as inclusive growth. According to the Asian Development Bank, economic growth without equal opportunity for people to access education, health and employment will only widen the poverty gap. World Bank adds the goal of achieving inclusive growth as a policy of reducing poverty [9]. In other words, inclusive growth is expected to provide opportunities for people, especially the middle to lower community to get a good standard of living such as education, health and employment opportunities that further ensure livelihood. In the end, inclusive growth aims to reduce the gap of income inequality between communities.

FIGURE 1.

THE WELFARE INDICATORS OF EAST JAVA, 2005-2015

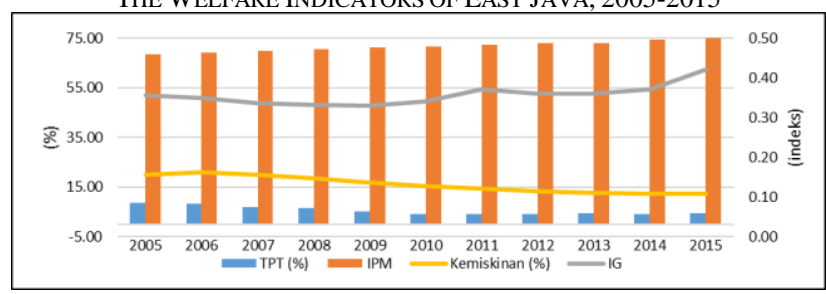

Source: BPS proceed, 2017

The Government of East Java has been focusing its policies to promote more inclusive growth since 2014. Nevertheless, Figure 1 above shows that development in East Java still faces a problem of the quality of economic growth that has not affected the poor. From 2005-2015, the human development index continued to increase despite not very significant. Similarly, the reduction of unemployment and poverty. However, in 2015 it was noted that the income inequality gap is widening. This indicates an increasingly severe depth of poverty.

As described in Neoclassical growth, [21] mentions the factors that determine economic growth including physical capital, human capital, 
and the use of technology. The Solow growth model is based on the calculation of the CobbDouglas production function, $\mathrm{Y}=\mathrm{f}(\mathrm{K}, \mathrm{L})$. Where the elasticity of output $(\mathrm{Y})$ depends on physical capital (K) and human capital (L). The Solow model is widely accepted by researchers to analyze the relationship between human capital and economic growth. Nevertheless, the frame of mind is not always consistent with empirical reality in an area. Later the Solow model was developed by Lucas (1988) as an endogenous growth that provides a deeper understanding of the formation of economic growth.

This study attempts to fill the gap between Solow's growth theory and empirical studies in East Java based on two main objectives: (i) to find out the relationship between government allocation for human capital improvement and economic growth and (ii) to determine the impact of public investment allocation on the welfare indicators of the community (components of the human development index are unemployment, poverty, and income inequality).

\section{LiterATURE REVIEW}

The model of economic growth continues to evolve from time to time. It began with the concept of macroeconomic growth by Keynes (1936). Over the next three years, Harrod-Domar (1939) developed the investment variable as the determining factor of growth. Further in 1956, Solow introduced a neoclassical growth model and was further developed by Lucas (1988) in an endogenous growth model. As a grand theory in this study, a neoclassical growth model was developed in an endogenous growth model.

In the Solow model there are several assumptions: (i) output (Y) depends on physical capital (K), human capital (L) and technology level (A); (ii) there is a decrease in marginal return of accumulation of production factor which means there is any additional capital increase output; and (iii) factors other than capital and labor are considered not as important in the growth process. Then, per capita growth rate in the long run is determined by the rate of technology used and the rate of population growth. According to Grenade (2011), the role of government to promote economic growth is measured through the existence of technological variables in the neoclassical model. The use of technology is described as a natural public good.

The use of technology in neoclassical models was developed with the concept of endogenous growth. The acceleration of economic growth depends on human capital investment, innovation and research and development ( $\mathrm{R} \& \mathrm{D})$. This indicates that the accumulation of capital and labor is important in creating growth, but it is necessary to encourage investment in increasing the productivity of capital and labor. As the development of neoclassical growth, the linkage between human capital and economic growth can create a quality economic growth. According to Romer (1994), the allocation for human capital investment versus physical capital has a spill over effect on increasing use of technology.

Several previous studies have suggested that there is a positive relationship between human capital investment and economic growth. Santos (2011) explains that there is a relation in quantity and quality of education to inclusive growth based on Solow theory. It was also found that the role of the government in allocating educational investment could accelerate inclusive growth in an area. Pritchett (2001) and Levine (2001) show that there is no significant relationship between physical capital accumulation and economic growth. Moreover, economic growth was created from an increase in investment in human capital.

Odit et al. (2010) and Safdari et al. (2010) explains that there is an effect of human capital accumulation on economic growth with the size of the ratio of highly educated population. Higher education reflects higher levels of technology use. Where, in developing countries the use of this technology does not significantly improve economic growth compared to developed countries. This is because the ratio of highly educated population is still very minimal compared to the total population. Pritchett (2001) adds that higher education will increase individual income but impact on the high supply of skilled labor which actually causes income inequality.

In the concept of inclusive growth is also explained about the relationship between human 
capital and the unemployment rate. Where increases in human capital accumulation have an impact on reducing unemployment in an area (Charles et al., 2010; Mroz \& Savage, 2006). Ho and Tan (2008) added that the accumulation of human capital in the form of knowledge and information transfer as well as skill enhancement will increase capacity and encourage a person to get a decent job. There is a relationship between human capital and poverty level. This hypothesis shows that the increase in human capital impacts on the increase in wages received and the impact on Azam poverty reduction (2011). One other component of welfare is income inequality. Yang et. Al (2009) explains the relationship between education inequality and income inequality in China. The inequality of education can make a person difficult to increase income, on the contrary low income makes a person more difficult to access high education.

Fontana and Srivastava (2009) examine the "four tigers" of Asia - Hong Kong, South Korea, Singapore and Taiwan - facing high economic growth with widening income inequality. With the allocation of investment in human capital, the country is not only able to reduce poverty but also increase the accumulation of physical capital. This causes the labor to be given a decent wage to improve labor productivity and a better standard of living.

\section{METHODS}

The approach used in this research is quantitative approach by focusing on one region (single country) that is East Java province in $2004-2015$. This approach was chosen in order to be able to give a specific recommendation for public policies setting in order to achieve inclusive growth in East Java. While, the method of data collection is by documenting the secondary data sourced from World Bank and Central Statistics Agency of East Java Province. The method of analysis using simultaneous regression analysis with two main equations, namely:

(i) multiple linear regression to determine the relationship between investment in human capital and economic growth:

$\log p e_{t}=\log p e_{t-1}+\log \operatorname{god}_{t}+\operatorname{logipm}_{t}+\operatorname{logapbdpend} d_{t}+\operatorname{logapbdpk}_{t}+e_{t}$ (ii) regression analysis to find out how the impact of human capital investment on welfare:

$$
P(\text { ipm })=\operatorname{logipm}_{t}+\log _{\text {tote }}+\operatorname{logapk}_{t}+e_{t}
$$

Where $\mathrm{P}(\mathrm{IK})$ is an index calculated based on the actual value-minimum value) / (maximum-value minimum) of the unemployment rate, inequality and poverty.

The operational definition of the variables:

\begin{tabular}{ll} 
Variables & \multicolumn{1}{c}{ Definition } \\
pe & : Total value-added of goods and services produced \\
& in an area in a given year. \\
pelag & : Total value-added of goods and services produced \\
& in an area in the previous year. \\
mod & $:$ Capital accumulation in an area in a given year \\
ipm & $:$ Human capital in an area in a given year \\
apk & $:$ Government spending on education \\
p ipm) & $:$ Government spending on social \\
& $:$ Human capital index measured by calculation \\
& (minimum value-actual) / (minimum maximum \\
& value) of unemployment rate, inequality and \\
& poverty.
\end{tabular}

\section{RESULTS AND DISCUSSION}

The technological variables in the endogenous growth model are defined as components that determine the acceleration of economic growth apart from the accumulation of physical capital and human capital. This study focuses on the performance of non-physical investment known as human resource investment. Human resource investment represents the amount of funds spent and the opportunity to earn an income during the investment process aimed at improving human quality. Human capital investment can be education investment, health, social security, infrastructure and so forth.

To know the existence of relationship between human capital investment with economic growth used regression analysis method at first equation. This equation is an equation based on an endogenous growth model in which economic growth is affected by the accumulation of physical capital, the quality of human capital, and the presence of technology in the form of increased 
human capital investment in education and social security. Regression results show that this model has a $\mathrm{R}^{2}$ (R-Squares) of $46 \%$. This shows that the percentage of contribution of independent variables (previous year economic growth, accumulation of physical capital, human capital and human capital investment) to the dependent variable (economic growth) of $46 \%$. This means that there are variables outside the model that are better able to describe this phenomenon.

Partially, economic growth in the previous year and the accumulation of physical capital did not significantly affect East Java's economic growth. Reinforced by previous research from Levine (2001) which explains that there is no significant relationship between the accumulation of physical capital with economic growth. Due to economic growth it is created from an increase in investment in human capital.

By including human capital investment variable in the form of government expenditure for education and social provision, it can be obtained less than $5 \%$ error rate for social expenditure and $10 \%$ for education expenditure. Where, every $1 \%$ increase on social expenditure will increase economic growth by $0.29 \%$ with the assumption of cateris paribus. In contrast, the increase in education expenditures by $1 \%$ actually lowered economic growth by $0.26 \%$ with the assumption of cateris paribus. This indicates that investment in human capital, especially in the field of education and health is able to encourage the acceleration of inclusive economic growth. On the contrary, the amount of expenditure in the field of education alone is not sufficient to encourage economic growth towards inclusive because the people of East Java in general have high accessibility to education.

The un-inclusivity of East Java is also seen in the first equation where the increase in human capital by $1 \%$ actually reduces the acceleration of economic growth by $6.8 \%$. The discrepancy in the theory of human capital that promotes economic growth is explained by Pritchett (2001) that higher education will increase individual income but has an impact on the high supply of scarce labor which actually causes income inequality. Thus, East Java's current economic growth has not led to inclusiveness because the high quality of human capital is only followed by some communities, but not equally distributed to the poor.

\begin{tabular}{|c|c|c|c|c|c|}
\hline Variables & Coefficients & $\mathbf{P}>|\mathbf{t}|$ & SE & R-sq & $\mathbf{P}$ \\
\hline \multicolumn{6}{|c|}{ 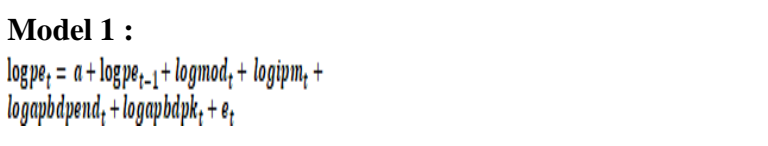 } \\
\hline $\mathrm{c}$ & 7.11 & $* *$ & 3.29 & \multirow[t]{6}{*}{0.46} & \multirow[t]{6}{*}{$*$} \\
\hline pelag & 0.22 & 0.51 & 0.33 & & \\
\hline $\bmod$ & 0.52 & 0.19 & 0.38 & & \\
\hline ipm & -6.82 & $* *$ & 3.37 & & \\
\hline ape & -0.26 & $* * *$ & 0.15 & & \\
\hline apk & 0.29 & $* *$ & 0.13 & & \\
\hline \multicolumn{6}{|c|}{$\begin{array}{l}\text { Model 2: } \\
P(\text { ipm })=a+\operatorname{logipm}_{t}+\log t k t e_{t}+\log a p k_{t}+e_{t}\end{array}$} \\
\hline$c$ & 50.21 & $*$ & 6.51 & \multirow[t]{4}{*}{0.90} & \multirow[t]{4}{*}{ * } \\
\hline ipm & 25.97 & $*$ & 3.12 & & \\
\hline tkte & -12.18 & $*$ & 0.46 & & \\
\hline apk & -1.25 & $*$ & 12.47 & & \\
\hline
\end{tabular}

Source: STATA 12, data proceed, 2017.

To understand how the impact of human capital investment on the welfare of the people of East Java is done by regressing the second equation. The welfare of society as measured by human capital indicates that the higher the value of $p(i p m)$ indicates that the welfare level decreases and the lower the $p$ value of (ipm) will indicate that the fewer people are unemployed, the lower the income inequality and the lower the number of the poor in East Java.

In line with the first equation, that the quality of human capital in East Java is not spread evenly and precisely causes the created economic growth does not lead to inclusiveness. In this equation, human capital actually widened the gap of income and poverty imbalances and also increased unemployment. This can be observed with the positive coefficient of ipm to $\mathrm{p}(\mathrm{ipm})$. That is, only a limited number of people with high levels of education, health and purchasing power enjoy growth. So, the welfare index of the community declines because many people are unemployed, poor and do not receive the appropriate wages for their livelihood. 
The structural transformation that occurred in the last few years shows that prime movers or the economic propulsion sector in East Java leads to the services and trade sectors. Therefore, in the second equation is added variable of labor quantity in tertiary sector. Workforce in the tertiary sector (services and trade) assumed workers with better health, education and purchasing power compared with people working in primary sector (agriculture) and secondary sector (processing industry). The simultaneous regression results show that an increase in the number of tertiary sector workers will encourage better welfare. It is hoped that the transition of people working in the agricultural sector to the services and trade sector is accompanied by comparable wage rates that encourage the reduction of unemployment and poverty.

The impact of human capital investment on the welfare level shows that each additional $1 \%$ of human capital investment in the form of social security will reduce unemployment, poverty and income inequality by $1.25 \%$. With the allocation of investment in human capital, the government not only able to reduce poverty but also increase the accumulation of physical capital. This is because labor is given a decent wage to improve labor productivity and a better standard of living.

\section{CONCLUSION}

Defining inclusive growth is the acceleration of economic growth followed by improving the quality of human resources and viable living standards to encourage development planners to develop appropriate and beneficial policies. This research is based on the theory developed by Lucas (1988) by adding the investment variable of human capital in increasing economic growth.

Regression results indicate that human capital investment, especially social budget allocation positively affects economic growth. Nevertheless, the accumulation of physical capital in East Java has no significant impact on economic growth. These findings illustrate the widening phenomenon of income inequality due to the quality of resources that are not evenly distributed. Accessibility of education, health and support of living standards is not felt by the poor.
The impact of human capital investment on public welfare is explained in the second equation. There is a positive relationship between $\mathrm{p}(\mathrm{ipm})$ and ipm and the negative relationship between $\mathrm{p}$ (ipm) and tertiary labor and apk. Simultaneously, the high quality of human resources will encourage development issues such as unemployment, income inequality and poverty. There is a need for social government budget allocation in the field of education, health, social security in order to encourage more inclusive growth.

Policy recommendations for stakeholders are human capital investment can be an alternative to accelerate economic growth in East Java. Human capital development policies can be used as key strategies in realizing inclusive growth. However, it is not enough just to increase the allocation of education but require greater fiscal space for allocation in other areas such as health and social security.

Based on the empirical findings that the more qualified human capital actually decreases the level of welfare, the second recommendation that can be given is the government needs to open employment opportunities in the tertiary sector such as services and trade. This sector is predicted to continue to grow more rapidly. The government needs to prepare human resources with higher education at the same time with a qualified skill. So it is expected that human capital investment can encourage the quality of people who are able to compete in the labor market.

\section{REFERENCES}

[1] Adejuwon, O. O., Ilori, M. O., \& Taiwo, K. A. (2016). Technology adoption and the challenges of inclusive participation in economic activities: Evidence from small scale oil palm fruit processors in southwestern Nigeria. Technology in Society. https://doi.org/10.1016/j.techsoc.2016.09.002

[2] Agénor, P. R., \& Canuto, O. (2015). Gender equality and economic growth in Brazil: A long-run analysis. Journal of Macroeconomics, 43 155-172. https://doi.org/10.1016/j.jmacro.2014.10.004

[3] Anand, R., Mishra, S., \& Peiris, S. J. (2013). Inclusive Growth Revisited: Measurement and Determinants. International Monetary Fund - Asia Pasific Department (Vol. 122). https://doi.org/10.5089/9781484323212.001

[4] Bank Indonesia. 2016. Kajian Ekonomi Regional Jawa Timur Triwulan 2016. http://www.bi.go.id/id/Default.aspx

[5] Bank Dunia. 2011. Diagnosa Pertumbuhan Ekonomi Jawa Timur: Mengidentifikasi Hambatan-Hambatan Utama Pertumbuhan yang Inklusif di Provinsi Terbesar Kedua di Indonesia. Jakarta: Bank Dunia.

[6] Bhattacharyya, S and Resosudarmo, B P. 2014. Growth, growth accelerations, and the poor: lessons from Indonesia. World Development, (Vol. 66): 154-165. 
[7] Burja, C., \& Burja, V. (2013). Education's contribution to sustainable economic growth in Romania. Procedia - Social and Behavioral Sciences, 81, 147-151. https://doi.org/10.1016/j.sbspro.2013.06.403

[8] Chatterjee, S. (2005). Poverty Reduction Strategies-Lessons from the Asian and Pacific Region on Inclusive Development. Asian Development Review, 22(1), 12-44.

[9] Felipe, J. (n.d.). Inclusive growth: Why is it important for developing Asia? Cadmus, I(4), 36-58.

[10] Jones, C. I., \& Klenow, P. J. (2010). Beyond GDP? Welfare across Countries and Time. Human Development, 106(9), 55. https://doi.org/10.3386/w16352

[11] Klasen, Stephan. 2010. Measuring and Monitoring Inclusive Growth: Multiple Definitions, Open Questions, and some Constructive Proposals. ADB Sustainable Development Working Paper Series No. 12.

[12] Kuncoro, Mudrajat. 2006. Ekonomika Pembangunan Teori, Masalah, dan Kebijakan (Edisi Keempat). Yogyakarta: UPP STIM YKPN.

[13] Mandlebe, W. (2014). Human Capital and Inclusive Growth: A Case Study of Botswana. Walden University. https://doi.org/10.1111/j.14678616.2008.00521.x Malik,

[14] Pandey, J. K., Chintu, A. K., \& Ranjan, R. (2014). Inclusive Growth In India : Some Empirical Facts. Jurnal Knowledge Horizons - Economics, 6(1), 2069.

[15] Pezzey, J. C. V, \& Burke, P. J. (2014). Towards a more inclusive and precautionary indicator of global sustainability. Ecological Economics, 106, 141-154. https://doi.org/10.1016/j.ecolecon.2014.07.008

[16] [Prentice Hall, Greene] Econometric analysis, 5th ed.pdf. (n.d.).

[17] Richard Samans, Jennifer Blanke, Gemma Corrigan, M. D. (2015). The Inclusive Growth and Development Report. Retrieved from http://www3.weforum.org/docs/Media/WEF_Inclusive_Growth.pdf

[18] Samans, R., Blanke, J., Corrigan, G., \& Drzeniek, M. (2015). Benchmarking Inclusive Growth and Development Discussion Paper. Switzerland.

[19] Sen, K. (2014). Inclusive growth: When may we expect it? when may we not? Asian Development Review, 31(1), 136-162 https://doi.org/10.1162/ADEV_a_00022

[20] Stata Corporation. (2001). Stata reference manual : release 7 (Vol. 3).

[21] Stiglitz, J. E. (2016). An agenda for sustainable and inclusive growth for emerging markets. Journal of Policy Modeling, (January), 25. https://doi.org/10.1016/j.jpolmod.2016.05.012

[22] Todaro, M. P dan Smith, S. C. 2011. Pembangunan Ekonomi/ Edisi Kesebelas, Jilid 1. Erlangga.

\section{Appendix}

Appendix 1. 2SLS

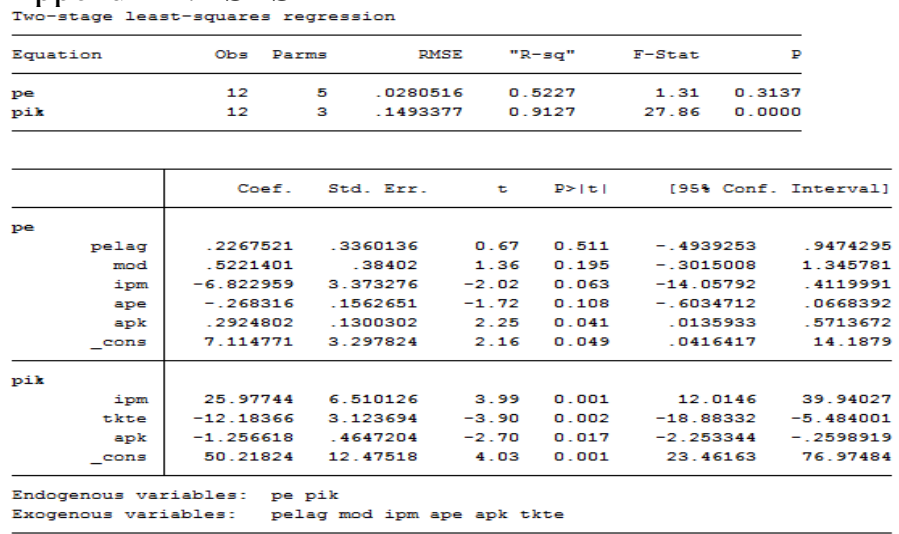


Appendix 2. 3SLS

\begin{tabular}{|c|c|c|c|c|c|c|}
\hline Equation & \multirow{2}{*}{$\begin{array}{ll}\text { obs } & \text { par } \\
12 & \\
12 & \end{array}$} & \multirow{2}{*}{$\begin{array}{r}\text { PMSE } \\
2050505 \\
252511\end{array}$} & \multicolumn{2}{|c|}{ "R-sq" } & chi2 & $\mathrm{P}$ \\
\hline $\begin{array}{l}\text { pe } \\
\text { pik }\end{array}$ & & & & $\begin{array}{l}4624 \\
9078\end{array}$ & $\begin{array}{rr}24.13 & 0.00 \\
122.16 & 0.00\end{array}$ & \\
\hline & Coef. & Std. $E_{x}$ & $z$ & $p>|z|$ & [958 Conf. & Intervalu \\
\hline $\begin{array}{r}\text { pelag } \\
\text { mod } \\
\text { ipm } \\
\text { ape } \\
\text { apk } \\
\text { cons } \\
\end{array}$ & $\begin{array}{r}.2869095 \\
.6651761 \\
-8.875737 \\
-.4038034 \\
. .385224 \\
9.754114 \\
\end{array}$ & $\begin{array}{r}.2126341 \\
.241413 \\
2.143687 \\
.0982278 \\
.0849425 \\
2.10739\end{array}$ & $\begin{array}{r}1.35 \\
2.76 \\
-4.14 \\
-4.11 \\
4.54 \\
4.63 \\
\end{array}$ & $\begin{array}{l}0.177 \\
0.006 \\
0.000 \\
0.000 \\
0.000 \\
0.000 \\
\end{array}$ & $\begin{array}{r}-.1298457 \\
-1920153 \\
-13.07729 \\
-.5653264 \\
.2187398 \\
5.623705 \\
\end{array}$ & $\begin{array}{r}.7036646 \\
1.13837 \\
-4.674188 \\
-.211280 \\
.5517081 \\
13.88452\end{array}$ \\
\hline $\begin{array}{c}\text { ipm } \\
\text { txte } \\
\text { apk } \\
\text { cons }\end{array}$ & $\begin{array}{r}23.35169 \\
-10.10876 \\
-1.434742 \\
43.04202\end{array}$ & $\begin{array}{l}5.117257 \\
2.283317 \\
.3666868 \\
9.397099\end{array}$ & $\begin{array}{r}4.56 \\
-4.43 \\
-3.91 \\
4.58\end{array}$ & $\begin{array}{l}0.000 \\
0.000 \\
0.000 \\
0.0000\end{array}$ & $\begin{array}{r}13.32205 \\
-14.58398 \\
-2.153435 \\
24.62405\end{array}$ & $\begin{array}{r}33.38133 \\
-5.635351 \\
-.716488 \\
61.49\end{array}$ \\
\hline pgex & 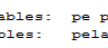 & ipm & & & & \\
\hline
\end{tabular}

